\title{
Pengaruh Pendekatan Matematika Realistik Terhadap Prestasi Belajar Matematika dan Sikap Bersahabat di Kelas IV SD
}

\author{
${ }^{1}$ Annisa Luthfiani, ${ }^{2}$ Sony Irianto, ${ }^{3}$ Ana Andriani \\ ${ }^{1,2,3}$ Pendidikan Guru Sekolah Dasar, Universitas Muhammadiyah Purwokerto, Indonesia \\ 12annisaluth835@gmail.com, ${ }^{2}$ sony pgsd@yahoo.com, ${ }^{3}$ ana.andriani@gmail.com ${ }^{3}$
}

\section{INFO ARTIKEL}

Riwayat Artikel:

Diterima : 17-07-2019

Disetujui : 01-10-2019

\section{Kata Kunci:}

Pendekatan Matematika

Realistik;

Prestasi Belajar;

Sikap Bersahabat.

\section{Keywords:}

Mathematical Approaches

Realistic;

Learning Achievement;

Friendly Attitude.

\begin{abstract}
ABSTRAK
Abstrak: Penelitian ini bertujuan untuk mengetahui pengaruh pendekatan matematika realistik terhadap prestasi belajar matematika dan sikap bersahabat di kelas IV Sekolah Dasar. Penelitian ini merupakan penelitian quasi eksperimental dengan desain Nonequivalent (Pretest-Posttest) Control Group Design. Sampel penelitian ini adalah siswa kelas IV SD sebanyak 42 siswa yang terbagi menjadi 20 siswa sebagai kelompok eksperimen dan 22 siswa sebagai kelompok kontrol. Penentuan sampel menggunakan cluster random sampling. Teknik pengambilan data dilakukan dengan instrumen prestasi belajar siswa melalui pretest dan posttest sedangkan instrumen sikap bersahabat didapatkan dengan angket menggunakan skala Likert. Pengujian hipotesis menggunakan uji-t pihak kanan, dimana t-hitung lebih besar dari t-tabel sehingga Ho ditolak dan Ha diterima. Hasil penelitian menunjukkan bahwa: (1) terdapat pengaruh antara pendekatan matematika realistik terhadap prestasi belajar siswa dengan t-hitung $=3,399 \geq \mathrm{t}$-tabel $=1,684 ;(2)$ terdapat pengaruh antara pendekatan matematika realistik terhadap sikap bersahabat siswa dengan t-hitung $=2,160 \geq \mathrm{t}$-tabel $=1,684$.
\end{abstract}

\begin{abstract}
This research aimed to find out the effect of realistic mathematics approach towards the students' learning achievement and friendly behavior on the fourth grade of Elementary School. This was a quasi-experimental research with Nonequivalent (pre-test and post-test) Control Group Design. The samples of this research were 42 fourth graders of Elementary School taken from two classes consisting of 20 students of the experiment class and 22 students of the control. The data of students'learning achievement were collected using pre-test and post-test, while the data of students' friendly behavior were collected using a questionnaire of Likert scale. To test the hypothesis of this study using the right $t$-test, where $t$-count was bigger than t-table so Ho will be rejected and Ha will be accepted. The results showed that: (1) there was an effect between realistic mathematics approach and the students' learning achievement with $t$-count $=3.399 \geq t$-table $=1.684$; (2) there was an effect between realistic mathematics approach and students' friendly behavior with $t$-count $=2.160 \geq$ t-table $=1.684$.
\end{abstract}

\section{A. LATAR BELAKANG}

Pendidikan merupakan suatu proses pembelajaran yang dilakukan secara sadar oleh sekelompok orang berupa pembelajaran pengetahuan, keterampilan dan kebiasaan yang dilakukan oleh generasi satu ke generasi berikutnya melalui pengajaran, pelatihan atau penelitian agar lebih baik (Lazwardi, 2017). Undang-undang No 20 tahun 2003 tentang Sistem Pendidikan Nasional, Pasal, sebagai berikut:

"Pendidikan nasional berfungsi untuk mengembangkan kemampuan dan potensi peserta didik agar menjadi manusia yang yang beriman dan bertakwa kepada Tuhan Yang Maha Esa, berakhlak mulia, sehat, berilmu, cakap, kreatif, mandiri dan menjadi warga negara yang demokratis serta bertanggung jawab" 
Mengembangkan kemampuan dan potensi yang dimiliki peserta didik, dapat dibantu oleh sekolah terutama dalam proses pembelajaran yang dilakukan oleh guru. Proses pembelajaran yang diberikan dapat menambah pengetahuan dan wawasan yang dimiliki oleh peserta didik (Sukri \& Widjajanti, 2015), (Bilda, 2016). Matematika memiliki peranan penting dalam kehidupan manusia. Banyak permasalahan yang kita temui harus diselesaikan dengan menggunakan ilmu matematika, seperti menghitung, mengukur dan lain sebagainya. Matematika sebagai ilmu dasar yang harus diajarkan pada anak didik untuk dapat menyelesaikan suatu permasalahan dari jenjang sekolah dasar hingga perguruan tinggi (Aziizu, 2015).

Matematika terbentuk dari pengalaman manusia dalam dunianya secara empiris. Kemudian pengalaman itu diproses di dalam dunia rasio, diolah secara analisis dengan penalaran di dalam struktur kognitif sehingga sampai terbentuk konsep-konsep matematika supaya konsep-konsep matematika yang terbentuk itu mudah dipahami oleh orang lain dan dapat dimanipulasi secara tepat, maka digunakan bahasa matematika atau notasi matematika yang bernilai global (univeral). Konsep matematika di dapat karena proses berpikir, karena itu logika adalah dasar terbentuknya matematika (Tiurlina, 2016 ).

Pembelajaran matematika dipandang sangat sulit dan menakutkan bagi siswa sekolah dasar. Matematika dianggap sangat sukar, sebagai ilmu hafalan tentang rumus, dan ilmu abstrak yang tidak berhubungan dengan realita sampai dengan ilmu yang membosankan. Cara pandang peserta didik ini disertai dengan cara guru dalam menyampaikan pelajaran matematika yang terkesan menakutkan, tidak menarik perhatian yang akhirnya dapat menciptakan prestasi belajar matematika yang rendah. Prestasi belajar merupakan pengetahuan yang dimiliki seseorang setelah mengalami proses pembelajaran dengan kemampuan memecahkan masalah yang diperoleh dari proses pembelajaran. Prestasi belajar merupakan hasil yang diperoleh seseorang setelah menempuh kegiatan belajar, sedangkan belajar pada hakekatnya merupakan usaha sadar yang dilakukan seseorang untuk memenuhi kebutuhannya (Mulyasa, 2013).
Siswa yang mengalami kesulitan dalam memahami materi yang diajarkan oleh guru, cenderung akan bertanya pada siswa yang lebih memahami materi yang disampaikan oleh guru yaitu pada siswa yang prestasi belajarnya bagus. Siswa yang tadinya tidak pernah bertanya kepada siswa yang pandai dengan terpaksa akan bertanya mengenai materi yang tidak dipahaminya. Menurut Zubaedi terdapat 18 nilai karakter salah satunya adalah sikap bersahabat yaitu tindakan yang memperlihatkan rasa senang berbicara, bergaul dan bekerja sama dengan orang lain (Zubaedi, 2011). Sikap dan tindakan ini dilakukan melalui komunikasi yang baik, berbicara yang sopan dalam hal bertanya sehingga siswa akan menjelaskannya dapat memahami apa yang disampaikan. Hal ini merupakan salah satu nilai karakter yaitu sikap bersahabat yang dapat membantu permasalahan siswa.

Hasil observasi dan wawancara peneliti kepada guru kelas IV, dengan hasil yang diperoleh adalah prestasi belajar matematika pada PAS (Penilaian Akhir Semester) Ganjil belum semua siswa memperoleh nilai di atas KKM yang telah ditentukkan. Siswa cenderung pasif di dalam pembelajaran, hanya mendengarkan apa yang disampaikan oleh guru sehingga prestasi pembelajaran yang didapat menjadi kurang maksimal. Pembelajaran yang disampaikan oleh guru masih menggunakan metode konfensional dalam artian masih menggunakan metode ceramah. Pembelajaran pada kurikulum 2013 diharapkan siswa yang lebih aktif dalam setiap pembelajaran. Fungsi guru disini hanya sebagai motivator siswa apabila merasa kesulitan.

Kesulitan siswa dalam memahami pelajaran matematika dalam hal perkalian, dan pembagian, pemecahan masalah, kemudian soal-soal yang berkaitan dengan soal cerita siswa cenderung masih berfikir dua kali dalam memahami soal tersebut. Proses belajar yang diberikan oleh guru dalam bentuk soal, siswa akan bisa mengerjakan apabila soal tersebut sama dengan contoh soal yang diberikan, apabila berbeda siswa merasa kesulitan dalam menyelesaikannya (Sugiman \& Aziz, 2015). Hal ini dikarenakan siswa hanya terampil atau biasa menghafal bentuk soal dan cara penyelesaiannya. Sehingga siswa lebih banyak pasif dan tidak terlibat secara aktif dalam pembelajaran yang dipelajarinya. 
Siswa yang belum memahami pelajaran yang disampaikan juga tidak mau bertanya kepada siswa yang sudah memahaminya, cenderung diam dalam pembelajaran karena merasa canggung apabila ingin bertanya kepada siswa yang pandai. Kebanyakan guru dalam mengajar sumber utama yang diberikan dari guru tersebut dan metode yang digunakan adalah ceramah yang dirasa membosankan dalam belajar matematika. Penggunaan pendekatan pembelajaran yang akan digunakan oleh guru nantinya dapat membantu proses pembelajaran menjadi lebih baik dan proses pembelajaran yang melibatkan peserta didik dapat membantu proses pembelajaran menjadi lebih menarik.

Pendekatan pembelajaran matematika banyak jenisnya, tergantung dengan pembelajaran yang akan disampaikan, karakter peserta didik serta kondisi kelas (Mulyati, 2017). Peneliti akan melaksanakan sebuah eksperimen dengan menggunakan pendekatan matematika realistik, dimana pendekatan matematika realistik merupakan proses pembelajaran yang menggunakan mediamedia konkrit disekitar, untuk memudahkan peserta didik dalam memahami pembelajaran. Media-media konkrit ini mudah dan sering ditemui dalam kehidupan sehari yang nantinya siswa dapat mengaplikasikannya sebagai bahan pembelajaran dan memberikan pemahaman lebih mendalam mengenai matematika terlebih khusus dalam materi pengumpulan dan penyajian data. Kemudian dapat membuat siswa lebih aktif, prestasi belajar matematika yang didapat lebih baik dan dapat mengkomunikasikannya dengan teman sebaya menjadi tidak canggung. Tak hanya siswa, dengan pendekatan matematika realistik dapat menambah pengetahuan guru dalam memberikan pembelajaran kepada siswa agar lebih aktif (Supardi, 2012).

Hamdani dalam Hidayati (2013) secara konkret, penerapan Pendekatan Matematika Realistik Indonesia dalam pembelajaran digambarkan dengan langkah-langkah operasional sebagai berikut: (1) Pemberian masalah oleh guru, (2) Penyelesaian masalah oleh siswa dengan cara mereka sendiri, (3) Siswa yang memiliki penyelesaian masalah yang berbeda-beda mempresentasikan hasil pekerjaannya, (4) Siswa lain memberikan tanggapan terhadap pekerjaan yang telah dipresentasikan, (5) Dari beberapa penyelesaian dan hasil diskusi, akhirnya melalui proses negosiasi siswa memilih penyelesaian yang paling baik, dan (6) Siswa mengakhiri kegiatan penyelesaian masalah dengan refleski (Hidayati, 2013).

Penelitian tentang pengaruh pendekatan RME sebelumnya sudah diteliti oleh peneliti lain yang berjudul "Pengaruh Pendekatan Matematika Realistik (PMR) terhadap Prestasi Belajar Matematika Siswa Kelas V SDK Ngudukelu. Berdasarkan perhitungan uji-t diperoleh bahwa thitung $=3,058$ dan t-tabel 2,021, artinya t-hitung lebih besar dari t-tabel maka hasil hipotesis observasi (Ho) ditolak dan hipotesis alternatif (Ha) diterima, maka terdapat perbedaan yang signifikan terhadap prestasi belajar matematika dengan menerapkan pendekatan matematika realistic (PMR) dari pada menerapkan pembelajaran konvensional (Melkior, 2016).

Penelitian dengan menggunakan Pendekatan Matematika Realistik sangat penting dilakukan kerena kebanyakan guru saat pembelajaran tidak menggunakan pendekatan di dalam sebuah pembelajaran untuk membantu siswa dalam memahami pelajaran (Natalia, 2017). Pendekatan matematika realistik dapat membantu siswa di SD N Karangnangka agar lebih bisa berkomunikasi dengan siswa lain dalam menghargai pendapat. Bagi guru, pendekatan matematika realistik dapat membantu siswa lebih memahami pelajaran karena permasalahan yang diberikan berkaitan dengan kehidupan nyata. Menggunakan pendekatan matematika realistik akan memudahkan siswa dalam memahami pelajaran dibandingkan pembelajaran saintifik (Ardana, 2018).

Oleh sebab itu, tujuan dari penelitian ini adalah untuk mengetahui pengaruh pendekatan matematika realistik terhadap prestasi belajar matematika dan sikap bersahabat di kelas IV Sekolah Dasar dengan metode eksperimen.

\section{B. METODE PENELITIAN}

\section{Jenis Penelitian}

Jenis penelitian ini berupa penelitian kuantitatif dengan menggunakan metode quasi eksperimental. Desain yang digunakan dalam penelitian ini adalah desain Nonequivalent (pretest-posttest) Control Group Design. Pada penelitian ini subjek dikelompokkan menjadi dua kelompok yaitu kelompok eksperimen dan kelompok kontrol yang 
diseleksi tanpa prosedur penempatan acak (Creswell, 2016). Waktu penelitian dilaksanakan pada semester genap selama 2 minggu dengan 4 kali pertemuan.

\section{Populasi Penelitian}

Populasi dalam penelitian ini seluruh siswa di kelas IV-A dan IV-B SDN X yang berjumlah 42 siswa. Sampel pada penelitian ini yaitu siswa kelas IV dengan jumlah siswa kelas IV-A yaitu 20 siswa dan jumlah siswa kelas IV-B yaitu 22 siswa. Teknik pengambilan sampel dalam penelitian ini menggunakan cluster random sampling yaitu pengambilan sampelnya bukan dari didasarkan pada individual, tetapi lebih didasarkan pada kelompok, daerah, atau kelompok subjek yang secara alami atau berkumpul bersama (Sugiyono, 2017). Kelompok (cluster) dalam hal ini adalah siswa kelas IV-A dan IV-B di SDN X yang keduanya memiliki kesempatan menjadi sampel, karena objek sama, maka peneliti terlepas dari sifat subjektif yang mengistimewakan satu atau beberapa objek untuk dijadikan sampel.

\section{Teknik Pengumpulan Data}

Teknik pengumpulan yang digunakan dalam penelitian ini adalah (1) tes yakni untuk data prestasi belajar matematika, (2) angket untuk data sikap bersahabat, dan (3) dokumentasi. Tes yang digunakan untuk mengukur prestasi belajar dengan menggunakan pretest diberikan untuk memberi gambaran awal tentang kemampuan peserta didik yang dicapai sebelum melakukan proses belajar mengajar pada mata pelajaran matematika. Posttest merupakan evaluasi akhir yang diberikan setelah guru menerapkan pembelajaran matematika menggunakan pendekatan matematika realistik pada kelompok eksperimen dan pendekatan saintifik pada kelompok kontrol.

Angket yang digunakan untuk mengukur sikap bersahabat adalah angket pretest yang diberikan untuk memberi gambaran awal tentang kemampuan peserta didik yang dicapai sebelum melakukan proses belajar mengajar pada mata pelajaran matematika. Angket posttest merupakan evaluasi akhir yang diberikan setelah guru menerapkan pembelajaran matematika menggunakan pendekatan matematika realistik pada kelompok eksperimen dan pendekatan saintifik pada kelompok kontrol. Skala penilaian yang digunakan dalam sikap bersahabat dalam instrumen ini memiliki 4 alternatif jawaban, yaitu Selalu (S), Sering (SR), Kadangkadang (KK) dan Tidak Pernah (TP), dimana masingmasing jawaban memiliki nilai tersendiri yaitu dari skor 1 sampai 4 sesuai dengan pernyataan positif ada negatif.

Soal dan pernyataan yang diberikan pada kelompok eksperimen dan kontrol terlebih dahulu dilakukan analisis instrumen penelitian. Analisis instrumen penelitian yaitu uji coba instrumen tes dengan uji validitas menggunakan rumus product moment, reliabilitas menggunakan rumus Alpha Cronbach, taraf kesukaran dan daya beda. Sedangkan uji coba instrumen non tes (angket) dengan uji coba validitas dan reliabilitas.

Berdasarkan hasil uji coba pada kelas $\mathrm{V}$ dan setelah diuji vaiditas butir tes, reliabilitas, taraf kesukaran dan daya beda maka diketahui bahwa hasil uji coba tes prestasi belajar yang diberikan kepada kelompok eksperimen dan kelompok kontrol sudah valid, reliabel, soal yang diberikan tergolong cukup. Sedangkan untuk angket sikap bersahabat yang diberikan kepada kelompok eksperimen dan kelompok kontrol sudah valid dan sudah reliabel tergolong tinggi.

\section{Analisis Data}

Data yang dianalisis pada penelitian ini adalah skor hasil posttest siswa kelompok eksperimen dan kelompok kontrol. Setelah data yang diperoleh dilakukan analisis data untuk menguji dengan skor rata-rata siswa kelompok eksperimen dan kontrol. Untuk mengetahui perbedaan besar prestasi belajar dan sikap bersahabat siswa materi pengumpulan dan penyajian data yang diajarkan menggunakan pendekatan matematika realistik pada kelompok eksperimen dan pendekatan saintiik pada kelompok kontrol di kelas IV SDN X maka dilakukan dengan langkah-langkah pengolahan data yakni: pemberian skor, uji normalitas menggunakan Chi-kuadrat, uji homogenitas menggunakan uji F, uji hipotesis (uji-t) pihak kanan dengan menggunakan Independent Sample T-test dengan perhitungan secara manual dan dengan bantuan program SPSS versi 20. Rumus uji hipotesis (uji-t) Independent Sample T-test adalah:

$$
\mathrm{t}=\frac{\overline{\mathrm{x}}_{1}-\overline{\mathrm{x}}_{2}}{\sqrt{\left(n_{1}-1\right) S_{1}^{2}+\left(n_{2}-1\right) S_{2}^{2}}} \sqrt{\frac{n_{1} \cdot n_{2}\left(n_{1}+n_{2}-2\right)}{n_{1}+n_{2}}}
$$

(Agus, 2016) 
dengan $\overline{\mathrm{x}}_{1}$ adalah rata-rata data kelompok eksperimen, $\bar{x}_{2}$ adalah rata-rata data kelompok kontrol, $S_{1}^{2}$ adalah varians data kelompok eksperimen, $S_{2}^{2}$ adalah varians data kelompok kontrol, $n_{1}$ adalah banyak data kelompok eksperimen, $n_{2}$ adalah banyak data kelompok kontrol.

\section{HASIL DAN PEMBAHASAN}

\section{Hasil Prestasi Belajar}

Penelitian prestasi belajar menghasilkan 2 data, yaitu data sebelum perlakukan dan data setelah diberikannya perlakuan pada kelompok eksprimen dan kelompok kontrol. Data sebelum perlakukan memuat data pretest pengumpulan dan penyajian data sedangkan data setelah perlakukan memuat data tentang posttest prestasi belajar peserta didik. Hasil skor pretest dan postest dari 42 siswa yang terdiri dari 20 siswa pada kelompok eksperimen dan 22 siswa pada kelompok kontrol. Hasil prestasi belajar matematika berupa aspek kognitif dengan menggunakan instrument tes berupa soal uraian sebanyak 5 soal. Data hasil pretest dan postest dapat dijabarkan ke dalam perhitungan yang lebih lengkap yakni rata-rata $\overline{\mathrm{x}}$, standar deviasi $(\mathrm{S})$, nilai tertinggi (T) dan nilai terendah (R). Perhitungan tersebut dapat dilihat pada Tabel 1 berikut ini:

Tabel 1. Rekapitulasi Data Nilai Pretest dan Posttest

\begin{tabular}{lllll}
\hline \multicolumn{1}{c}{ Tipe Test } & \multicolumn{1}{c}{$\mathbf{\mathbf { x }}$} & $\mathbf{S}$ & $\mathbf{T}$ & $\mathbf{R}$ \\
\hline Pretest Eksperimen & 56 & 13,23 & 72 & 24 \\
\hline Pretest Kontrol & 54 & 16,5 & 76 & 28 \\
\hline Posttest Eksperimen & 76,6 & 18,91 & 100 & 44 \\
\hline Posttest Kontrol & 56,55 & 19,59 & 92 & 36 \\
\hline
\end{tabular}

Sebelum menguji hipotesis maka data prestasi belajar harus diuji normalitas dan homogenitas. Adapun hasil uji normalitas data sesuai Tabel 2 berikut ini:

Tabel 2. Output SPSS Uji Normalitas Prestasi Belajar

\begin{tabular}{llllllll}
\hline \multicolumn{7}{c}{ Tests of Normality } \\
\hline & \multicolumn{3}{c}{$\begin{array}{c}\text { Kolmogorov- } \\
\text { Smirnov }\end{array}$} & \multicolumn{4}{c}{ Shapiro-Wilk } \\
\cline { 2 - 8 } Kelas & Statistic & df & Sig. & Statistic & df & Sig. \\
\hline $\begin{array}{l}\text { Pretest } \\
\text { Eksperimen }\end{array}$ & .181 & 20 & .084 & .906 & 20 & .053 \\
\hline $\begin{array}{l}\text { Pretest } \\
\text { Kontrol }\end{array}$ & .142 & 22 & $.200^{*}$ & .917 & 22 & .066 \\
\hline $\begin{array}{l}\text { Postest } \\
\text { Eksperimen }\end{array}$ & .160 & 20 & .193 & .907 & 20 & .057 \\
\hline $\begin{array}{l}\text { Posttest } \\
\text { Kontrol }\end{array}$ & .179 & 22 & .065 & .903 & 22 & .125 \\
\hline
\end{tabular}

Berdasarkan Tabel 2 di atas, hasil uji Liliefors dapat dibaca pada kolom Shapiro-Wilk karena jumlah siswa kurang dari 50. Uji Shapiro-Wilk nilai pretest kelompok eksperimen nilai Sig $=0,053>0,05$ dan pretest kelompok kontrol nilai Sig $=0,066>$ 0,05. Nilai posttest kelompok eksperimen Sig $=0,057$ $>0,05$ dan posttest kelompok kontrol $\mathrm{Sig}=0,125>$ 0,05 Terlihat bahwa dari kedua uji tersebut dapat di simpulkan bahwa data nilai pretest dan posttest kelompok eksperimen dan kontrol berdistribusi normal dengan nilai Signifikasi lebih dari 0,05. Selanjutnya, untuk hasil uji homogenitas data dapat dilihat pada Tabel 3 dan Tabel 4 berikut ini.

Tabel 3. Output SPSS Uji Homogenitas Pretest

\begin{tabular}{|c|c|c|c|}
\hline Levene Statistic & df1 & df2 & Sig. \\
\hline 2.111 & 1 & 40 & .154 \\
\hline
\end{tabular}

Tabel 4. Output SPSS Uji Homogenitas Posttest

\begin{tabular}{cccc}
\hline Levene Statistic & df1 & df2 & Sig. \\
\hline .031 & 1 & 40 & .860 \\
\hline
\end{tabular}

Berdasarkan Tabel 3 dan 4 di atas, hasil output atau hasil SPSS di atas diperoleh pretest prestasi belajar nilai Sig. $=0,154>0,05$, sedangkan pada posttest nilai Sig. $=0,860>0,05$ dengan demikian dapat disimpulkan bahwa kedua data pretest dan posttest tersebut memiliki varians yang homogen.

Hipotesis merupakan kesimpulan yang ditarik sebagai jawaban sementara terhadap masalah penelitian. Uji hipotesis prestasi belajar peserta didik kelompok eksperimen dan kelompok kontrol menggunakan uji t secara manual pada Tabel 5 .

Tabel 5. Hasil Uji t Prestasi Belajar Matematika

\begin{tabular}{crcc}
\hline Data & $\mathbf{t}_{\text {tabel }}$ & $\mathbf{t}_{\text {hitung }}$ & Keputusan \\
\hline Prestasi Belajar & 1,684 & 3,399 & Ha diterima \\
\hline
\end{tabular}

Berdasarkan Tabel 5 di atas, hasil uji-t (hipotesis) dapat dilihat bahwa $t_{\text {hitung }}>t_{\text {tabel }}$ yaitu 3,399 $>1,684$. Menunjukkan bahwa Ha diterima dan Ho ditolak yang berarti bahwa untuk prestasi belajar kelompok eksperimen dan kontrol terdapat pengaruh pendekatan matematika realistik terhadap prestasi belajar matematika materi pengumpulan dan penyajian data di kelas IV Sekolah Dasar.

\section{Hasil Angket}

Dari sebaran angket menghasilkan 2 data, yaitu (1) data angket pretest yang diberikan sebelum diakukannya pembelajaran dan (2) data angket posttest yang diberikan kepada siswa setelah 
mengikuti proses pembelajaran, dimana kelompok eksperimen diberikan perlakuan dengan menggunakan pendekatan matematika realistik sedangkan kelompok kontrol diberikan perlakuan dengan menggunakan pendekatan saintifik. Hasil angket sikap bersahabat dengan menggunakan skala Likert dengan 10 pernyataan. Data hasil angket awal dan akhir dapat dijabarkan ke dalam perhitungan yang lebih lengkap yakni rata-rata $\overline{\mathrm{x}}$, standar deviasi $(\mathrm{S})$, nilai tertinggi (T) dan nilai terendah (R). hasil perhitungan tersebut dapat dilihat pada Tabel 6 berikut ini:

Tabel 6. Rekapitulasi Data Angket Pretest dan Posttest

\begin{tabular}{lcccc}
\hline \multicolumn{1}{c}{ Angket } & $\overline{\mathbf{x}}$ & $\mathbf{S}$ & $\mathbf{T}$ & $\mathbf{R}$ \\
\hline Pretest Eksperimen & 30,15 & 5,12 & 38 & 21 \\
\hline Pretest Kontrol & 30,18 & 5,94 & 39 & 21 \\
\hline Posttest Eksperimen & 32,85 & 4,39 & 39 & 25 \\
\hline Posttest Kontrol & 29,82 & 4,68 & 37 & 22 \\
\hline
\end{tabular}

Sebelum menguji hipotesis maka data prestasi belajar harus diuji normalitas dan homogenitas. Adapun hasil uji normalitas data sesuai Tabel 7 berikut ini:

Tabel 7. Output SPSS Uji Normalitas Angket Pretest dan Posttest

\begin{tabular}{lccccccc}
\hline \multicolumn{7}{c}{ Tests of Normality } \\
\hline & \multicolumn{3}{c}{$\begin{array}{c}\text { Kolmogorov- } \\
\text { Smirnova }\end{array}$} & \multicolumn{5}{c}{ Shapiro-Wilk } \\
\cline { 2 - 9 } Kelas & Statistic & df & Sig. & Statistic & df & Sig. \\
\hline Pretest Eksp. & .174 & 20 & .115 & .935 & 20 & .192 \\
\hline Pretest Kont. & .137 & 22 & $.200^{*}$ & .920 & 22 & .078 \\
\hline Posttest Eks. & .163 & 20 & .169 & .920 & 20 & .099 \\
\hline Posttest Kon. & .191 & 22 & .036 & .934 & 22 & .152 \\
\hline
\end{tabular}

Berdasarkan Tabel 7 di atas, hasil uji Liliefors dapat dibaca pada kolom Shapiro-Wilk karena jumlah siswa kurang dari 50. Uji Shapiro-Wilk nilai data angket pretest kelompok eksperimen nilai Sig. $=$ 0,192 > 0,05 dan nilai data angket pretest kelompok kontrol nilai Sig. $=0,078>0,05$. Sedangkan data nilai angket posttest kelompok eksperimen nilai Sig. = 0,099 > 0,05 dan angket posttest kelompok kontrol nilai Sig $=0,152>0,05$. Terlihat bahwa dari kedua uji tersebut dapat disimpulkan data nilai angket kelompok eksperimen dan kontrol berdistribusi normal dengan nilai signifikasi lebih dari 0,05. Selanjutnya, hasil uji homogenitas sesuai Tabel 8 dan Tabel 9 berikut ini.

Tabel 8. Output SPSS Uji Homogenitas Angket Pretest

\begin{tabular}{rrrrr} 
Levene Statistic & df1 & df2 & Sig. \\
\hline .629 & 1 & 40 & .432 \\
\hline
\end{tabular}

Tabel 9. Output SPSS Uji Homogenitas Angket Posttest

\begin{tabular}{crrrr} 
Levene Statistic & df1 & \multicolumn{1}{c}{ df2 } & \multicolumn{1}{c}{ Sig. } \\
.197 & & 1 & 40 & .660 \\
\hline
\end{tabular}

Berdasarkan Tabel 8 dan 9 di atas, hasil output atau hasil SPSS di atas pada uji homogenitas angket pretest diperoleh nilai Sig 0,432>0,05, sedangkan pada angket posttest diperoleh 0,660 dengan demikian dapat disimpulkan bahwa kedua data angket pretest dan posttest tersebut memiliki varians yang homogen.

Hipotesis merupakan kesimpulan yang ditarik sebagai jawaban sementara terhadap masalah penelitian. Uji hipotesis sikap bersahabat peserta didik kelompok eksperimen dan kelompok kontrol menggunakan uji-t pada penghitungan secara manual.

Tabel 10. Hasil Uji-t Sikap Bersahabat

\begin{tabular}{crc}
\hline Data & $\mathbf{t}_{\text {tabel }}$ & $\mathbf{t}_{\text {hitung }}$ \\
\hline Angket Bersahabat & 1,684 & 2,160 \\
\hline
\end{tabular}

Berdasarkan Tabel 10 di atas, hasil uji-t (hipotesis) dapat dilihat bahwa $t_{\text {hitung }}>t_{\text {tabel }}$ yaitu $2,160>1,684$, sehingga dapat disimpulkan bahwa Ho ditolak dan Ha diterima yang berarti bahwa untuk sikap bersahabat kelompok eksperimen dan kontrol terdapat pengaruh pendekatan matematika realistik terhadap sikap bersahabat materi pengumpulan dan penyajian data di kelas IV Sekolah Dasar.

\section{SIMPULAN DAN SARAN}

Berdasarkan hasil analisis data dan pembahasan, dapat disimpulkan bahwa (1) terdapat pengaruh pendekatan matematika realistik terhadap prestasi belajar matematika materi pengumpulan dan penyajian data di kelas IV Sekolah Dasar. Siswa terlibat langsung dalam proses menyelesaikan sebuah permasalahan yang diberikan dan menjadi lebih menyenangkan dalam mengikuti proses pembelajaran, (2) terdapat pengaruh pendekatan matematika realistik terhadap sikap bersahabat pada materi pengumpulan dan penyajian data di kelas IV Sekolah Dasar. Siswa lebih menghargai pendapat siswa lain dalam menyelesaikan permasalahan yang diberikan dan lebih berani dalam berkomunikasi dengan siswa lain.

Selanjutnya, penulis menyarankan pelaksanaan pembelajaran menggunakan pendekatan matematika realistik harus memperhatikan permasalahan yang beragam agar siswa dapat lebih luas dalam menyelesaikan permasalahan yang diberikan, kemudian guru harus lebih kreatif dalam memanfaatkan sarana dan prasarana yang dapat menunjang proses pembelajaran dengan menggunakan pendekatan matematika realistik. 


\section{REFERENSI}

Agus, R. N. (2016). Efektivitas Pembelajaran Matematika Melalui Pendekatan Realistic Mathematics Education (RME) Dengan pemecahan Masalah Ditinjau Dari Gaya Belajar Siswa. JIP STIKIP Kusuma Negara, 7(2), 77-90.

Ardana, N. M. S. (2018). Meningkatkan Hasil Belajar Siswa Kelas XI SMK Melalui Pembelajaran RME Pada Materi Trigonometri. JTAM / Jurnal Teori Dan Aplikasi Matematika, 2(2), 166-169. https://doi.org/10.31764/jtam.v2i2.724

Aziizu, B. Y. A. (2015). Tujuan Besar Pendidikan Adalah Tindakan. Prosiding Penelitian Dan Pengabdian Kepada Masyarakat, 2(2), 295-300. https://doi.org/10.24198/jppm.v2i2.13540

Bilda, W. (2016). Pendidikan Karakter Terencana Melalui Pembelajaran Matematika. Jurnal Pendidikan Matematika, 2(1), 46-53.

Creswell, J. W. (2016). Research Design: Pendekatan Metode Kualitatif, Kuantitatif, dan Campuran. In SAGE Publication.

Hidayati, K. (2013). Pendekatan Pendidikan Matematika Realistik Indonesia di SD Negeri 179 Palembang. Jurnal Cendekia, 11(1), 163-181.

Lazwardi, D. (2017). Manajemen Kurikulum Sebagai Pengembangan Tujuan Pendidikan. Jurnal Kependidikan Islam, 7(1), 99-112.

Melkior, W. (2016). Pengaruh Pendekatan Matematika Realistik (PMR) Terhadap Prestasi Belajar Matematika Siswa Kelas V SDK Ngedukelu Kacamatan Bajawa Tahun Pelajaran 2014/2015. Jurnal Ilmiah Pendidikan Citra Bakti, 3(1), 23-32.

Mulyasa. (2013). Pengembangan dan Implementasi Kurikulum 2013. Bandung: Remaja Rosdakarya.

Mulyati, A. (2017). Pengaruh Pendekatan RME terhadap Kemampuan Pemecahan Masalah Siswa pada Materi Operasi Hitung Campuran di Kelas IV SD IT Adzkia I Padang. Jurnal Didaktik Matematika, 4(1), 90-97. https://doi.org/10.24815/jdm.v4i1.8484

Natalia, S. (2017). Realistic Mathematics Education: Suatu Langkah Mendidik Berpikir Matematis. Jurnal Dinamika Pendidikan, 10(1), 81-96.

Supardi, S. U. (2012). Pengaruh Pembelajaran Matematika Realistik Terhadap Hasil Belajar Matematika Ditinjau Dari Motivasi Belajar. Cakrawala Pendidikan, 2, 244-255.

Sugiman, \& Aziz. (2015). Analisis Kesulitan Kognitif Dan Masalah Afektif Siswa Sma Dalam Belajar Matematika Menghadapi Ujian Nasional. Jurnal Riset Pendidikan Matematika, 2(2), 162-147.

Sugiyono. (2017). Pendekatan Kuantitatif, Kualitatif, Kombinasi, R\&D dan Penelitian Evaluasi. Bandung: Alfabeta

Sukri, Y. F., \& Widjajanti, D. B. (2015). Pengaruh Pendekatan Rme Terhadap Motivasi dan Prestasi Belajar Siswa SD Melalui Pembelajaran TematikIntegratif. Jurnal Prima Edukasia, 3(2), 227-235. https://doi.org/10.21831/jpe.v3i2.6503

Tiurlina. (2016). Tes Diagnostik Kesulitan Belajar Dan Pengajaran Remedial Untuk Meningkatkan Hasil Belajar Matemetika di SDN 7 Serang. EduHumaniora
/ Jurnal Pendidikan Dasar Kampus Cibiru, 5(2), 128134. https://doi.org/10.17509/eh.v5i2.2844

Zubaedi. (2011). Desain Pendidikan Karakter: Kompetensi dan Aplikasinya dalam Lembaga Pendidikan. Jakarta: Kencana Prenada Media Group. 